Exégesis védica, doctrina vedānta, hermenéutica del $R g$ Veda, vidente védico Vāmadeva, realización divina

\title{
LA REALIZACIÓN DIVINA SUGERIDA POR VĀMADEVA: UN ESTUDIO SOBRE LA TRADICIÓN EXEGÉTICA VÉDICA Y VEDĀNTA DE LOS HIMNOS 4.26 Y 4.27 DEL RG VEDA ${ }^{1}$
}

\author{
ANSELMO HERNÁNDEZ QUIROZ \\ El Colegio de México
}

Ustedes dos son ciertamente los Señores de la región de la luz, Indra y Soma, los guardianes de los rayos de luz, los regentes que nutren nuestras intuiciones. ${ }^{2}$

\section{Introducción}

El $R g$ Veda (ca. siglo XII a.e.c.) es el texto más antiguo de la literatura sánscrita que nos ha llegado. Se compone de himnos (sūktas) ordenados en diez ciclos (mandalas). Estos últimos pueden dividirse, según sus compositores, en dos grandes grupos: i) del segundo al séptimo, y ii) el primero, el octavo, el noveno y el décimo. Cada uno de los ciclos que pertenecen al primer grupo se relaciona con un vidente (rssi) primario, mientras que los del segundo grupo se asocian con más de cien videntes en total.

El cuarto ciclo se asocia casi en su totalidad con el vidente védico Vāmadeva, quien, de manera particular en los himnos 4.26 y 4.27, sugiere el tema de la realización divina, es decir,

Este artículo fue recibido por la dirección de la revista el 29 de enero de 2015 y aceptado para su publicación el de 23 de marzo 2015.

${ }^{1}$ Agradezco a Óscar Figueroa por sus valiosísimas sugerencias respecto a las versiones previas de este artículo.

2 The Rigveda: Metrically Restored Text, eds. Karen Thomson y Jonathan Slocum, Austin, The University of Texas, s.f., libro 9, himno 19, verso 2: yuvám hí stháb súvarpatī indraś ca soma gópatī. iśáná pipyatạ̣ dhiyah. En adelante las referencias que se tomen de aquí se citarán como: $\operatorname{Rg}$ Veda 9.19.2. 
de la identificación personal con los dioses. ${ }^{3}$ Vāmadeva recurre además en ambos himnos al empleo de metáforas que implican como su vehículo la liberación de un halcón, el robo del soma traído desde la región suprema y la posterior embriaguez provocada por la ingestión de esta excelente bebida que gusta sobremanera a los dioses. Cabe señalar que tanto Śankara (ca. siglo VIII) como Sāyaña (ca. siglo XIV) utilizaron de manera particular el verso sacro (mantra) 4.26.1 para fundamentar posteriormente cada uno su propia exégesis acerca de la realización divina.

En este artículo ofrezco un breve recorrido textual que interconecta la tradición exegética védica con la tradición vedānta, respecto tanto a la versión no dualista, representada por Śankara, como a una versión monista que, tal como se argumentará, es representada por Sāyaṇa. En la primera sección hago una nueva traducción de ambos himnos con notas recogidas principalmente de los siguientes textos: Aitareya Brähmana, Nirukta, Aștādhyaȳī, Bṛhaddevatā y Sarvānukramaṇi, en tanto que reviso aquí los comentarios de Sāyana acerca de la realización divina. En la segunda sección presento, en retrospectiva, algunos nexos entre la filosofía védica tardía y la filosofía vedān$t a$, a través de citas recogidas de algunos textos upanishádicos clásicos y los Brabma sütras, siguiendo de cerca ahora los comentarios de Śankkara, también sobre la realización divina. Mi hipótesis es que en el pensamiento védico temprano la doctrina de la realización divina se codificó en términos teístas y, después, en el tardío, en términos filosóficos impersonales.

A continuación se ofrece un mapa esquemático con las fechas aproximadas de los textos a los que se hará especial referencia en ambas secciones: ${ }^{4}$

${ }^{3}$ Se ha preferido emplear el término "realización divina" para denotar que esta experiencia es un "darse cuenta de que la persona es idéntica a una esencia divina". En este sentido, queda implícito que hay tanto una "comunión" como una "identificación" con los dioses y los videntes, quienes participan también de la misma esencia, como se verá más adelante.

${ }^{4}$ Las fechas de composición del Nirukta y el Sarvānukramañ más debatidas entre los textos que retomamos. Se sigue la opinión de Sarup y Witzel respectivamente. 
Mapa esquemático de los textos primarios empleados para la traducción, notas y citas

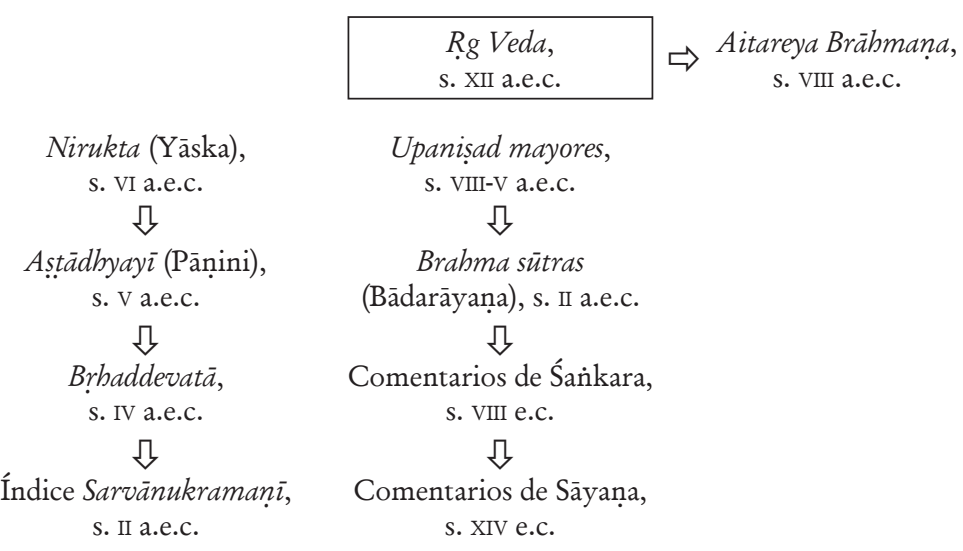

\section{Traducción y notas a los himnos 4.26 y 4.27 del $R g$ Veda}

El Rg Veda se compone de grupos ordenados de himnos (sūktas) dedicados a uno o varios dioses en particular. La unidad básica de cada himno es el verso sacro (mantra), cuyas propiedades distintivas son: que prosigue una determinada métrica según una medida prosódica de tres tiempos, que se acentúa según el empleo de tres tonos y que se concatena según distintos patrones cíclicos. El tema de los himnos es principalmente la adoración, el elogio y la invocación de los dioses. Una pauta para el ordenamiento de los ciclos o grupos de himnos es su clasificación por familias. Los ciclos que van del segundo al séptimo conforman el núcleo más antiguo del $\mathrm{Rg}$ Veda y fueron compuestos cada uno por un solo vidente y su linaje. De ahí que se denominen ciclos familiares. El cuarto ciclo agrupa los himnos del vidente Vāmadeva (55) y su linaje (3). Una característica distintiva de estos himnos es que su lenguaje es muy simbólico y enigmático.

En esta sección estudiaré la realización divina sugerida por el vidente Vāmadeva, es decir, la identificación personal con los dioses declarada por él en los himnos 4.26 y 4.27. Al final 
se expondrá una breve interpretación psicológica basada en el tenor, el vehículo y el fundamento de las principales metáforas empleadas aquí. Para ello es necesario presentar en primer lugar una traducción literal de ambos himnos para luego hacer anotaciones. Cabe destacar que estos dos himnos védicos ya han sido estudiados previamente de manera conjunta por Knipe, si bien desde la perspectiva de la historia de las religiones y con un enfoque comparativo, con el cual describe los sustratos mitológicos antiguos que hay entre diversos pueblos acerca de la leyenda de un ave divina que roba una planta sagrada en beneficio de un hombre heroico. ${ }^{5}$ En lo que sigue haré referencia a este trabajo en los lugares donde sea más adecuado mostrar las divergencias y los encuentros de pensamiento.

\section{Himno $4.26^{6}$}

1a. Yo era Manu y Sūrya, yo soy el vidente sabio inspirado Kakșīvat.

1b. Yo subyugo a Kutsa, el hijo de Arjuna; yo soy el poeta Ușanas, ¡mírenme!

2a. Yo di la tierra al noble, yo [di] la lluvia para el donante mortal.

2b. Yo guié las aguas sonantes, los dioses se mueven según mi voluntad.

3a. Yo, ebrio, rompí en pedazos las noventa y nueve ciudadelas de Śambara.

3b. [Hice] la centésima una residencia con una extensión total, cuando protegí [hice prosperar] a Divodāsa, Atithigva.

${ }^{5}$ David M. Knipe, “The Heroic Theft: Myths from Rgveda Iv and the Ancient near East", History of Religions, vol. 6, núm. 4, mayo de 1967, pp. 328-360.

${ }^{6}$ 1a. ahám mánur abhavm súryaś cāhám kakșîuāim ṛ̛ir asmi víprab!

1b. ahám kútsam ārjuneyám nyrñe 'bám kavír uśánā páśyatā mā ll

2a. ahám bhúmim adadām áryāyāhám vurstịm dāsúse mártyāya I

2b. ahám apó anayam vāvaśāná máma devăso ánu kétam àyan ॥

3a. ahám púro mandasānó vy éram náva sākám navatîh śámbarasya I

3b. śatatamám veśyàm sarvátātā dívodāsam atithigvám yád ávam ॥

4a. prá sú sá víbbyo maruto vír astu prá śyenáb śyenébhya āsupátvā I

4b. acakráyā yát svadháyā suparnó havyám bháran mánave devájustam II

5a. bhárad yádi vír áto vévijānaḥ pathórúnā mánojavā asarji I

5b. tûyam yayau mádhunā somyénotá śrávo vivide śyenó átra II

6a. rjīpí śyenó dádamāno amśúm parāvátab śakunó mandrám mádam I

6b. sómam bharad dādṛhānó devávān divó amúsmād úttarād ādáya ll

7a. ādáya śyenó abharat sómam sahásram savâm ayútam ca sākám |

7b. átrā púramdhir ajahād árạtīir máde sómasya mūrá ámūrah $\|$. 
4a. ¡Oh, Maruts! Que este hermoso pájaro sobrepase a las demás aves, que el halcón, rápido y alado, [vaya] al frente de los halcones.

4b. El de perfectas alas mediante un carro sin ruedas trae a Manu la ofrenda que complace a los dioses.

5a. Cuando el pájaro de pujante energía [vino] desde allá, se movía rápido como el pensamiento por los amplios [cursos] del camino.

5b. El halcón obtuvo la gloria allá y vino rápidamente con el soma melifluo.

6a. El poderoso halcón [voló] rectamente desde la región que está más allá tomando por la fuerza el [soma] que embriaga,

6b. firme en su fortaleza y endiosado trayendo el soma que tomó desde el lugar más elevado, desde ese cielo.

7a. El halcón tomó y trajo el soma para miles de extracciones y diez mil más.

7b. En tanto esto, el munificente [Indra] en su embriaguez de soma mató a los enemigos, el sabio [destruyó] a los tontos.

\section{Himno $4.27^{7}$}

1a. Mientras estaba aún en el útero, yo conocí en orden todos los nacimientos de estos dioses.

1b. Una centena de ciudadelas de hierro me guardaron, ahora [como] un halcón forcé mi salida con vigor a través [de ellas].

2a. Él [el útero] me gestó no sin [que yo tuviese] disgusto, mediante la fuerza salí de él.

2b. El munificente [Indra] en su movimiento asesinó a los enemigos y luego estando lleno de fuerza atravesó los vientos.

3a. Cuando el halcón envió su grito sonante desde el cielo hacia abajo, [los guardianes del soma] discreparon si ésa era o no [la bebida robada] para Indra.

7 1a. gárbhe nú sánn ánv esām avedam ahám devánām jánimāni viśvā ।

1b. śatám mā púra áyașīr araksann ádha śyenó javásā nír adīyam II

2a. ná ghā sá mám ápa jósam jabhārābhí àsa tvákșasā vīryèna I

2b. îrmá púramdhir ajabād árātīr utá vátāim atarac chúśuvānab ॥

3a. áva yác chyenó ásvand ádha dyór ví yád yádi vâta ühúh púramdhim I

3b. srjád yád asmā ávaba ksipáj jyâm kriśánur ástā mánasā bhuranyán II

4a. rjipyá im indrāvato ná bhujyúm śyenó jabhāra brható ádhi snób |

4b. antáḅ patat patatry àsya parnám ádha yámani prásitasya tád véb ॥

5a. ádha śvetám kaláśam góbhir aktám āpipyānám maghávā śukrám ándhab ।

5b. adbvaryúbhih práyatam mádbvo ágram indro mádāya práti dhat píbadhyai. śúro mádāya práti dhat píbadhyai ll. 
3b. Entonces Kŕśānu, liberando la cuerda del arco, lanzó ciertamente [su flecha] en contra, con la mente lo persiguió velozmente.

4a. Erguido en el vuelo, desde ahí, de la gran cima, el halcón cargó [el soma] como [los Aśvins cargaron] a Bhujyu desde el mundo de Indra.

4b. Esa ave [divina], apresurándose ahora en sus cursos, perdió [en el conflicto] una pluma caída del medio de su [cuerpo].

5a. ¡Que ahora Maghavān [el generoso Indra] se satisfaga con el alimento puro ofrecido por los [sacerdotes] Adhvaryu, bebiendo de la copa blanca rociada con leche!

5b. QQue el néctar puesto enfrente de Indra sea para que beba y se embriague! $\mathrm{Q}$ ue lo puesto [enfrente de] el poderoso sea para que beba y se embriague!

Ambos himnos se leen tradicionalmente en conjunto y al parecer hay una similitud temática que así lo justifica. De entrada, pienso que es posible dividir los temas abordados en tres: i) versos sacros de autoalabanza (4.26.1-3; 4.27.1); ii) versos sacros de elogio (4.26.4-6; 4.27.2-4), y iii) dos versos sacros de instrucción ritual (4.26.7; 4.27.5), de los cuales el primero parece ser más simbólico que factual. Debido a los epítetos utilizados, el dios que se adora principalmente es Indra, el cual, en el verso 4.27.1, se describe a sí mismo como un "halcón”, y esta identificación es la base para el elogio que se hace de su hazaña; a saber, haber forzado su camino a través de una serie de ciudadelas para lograr la obtención del soma y traerlo desde la región que está más allá.

En este sentido, me parece que es más natural conservar un solo interlocutor para cada verso sacro, además de que la comparación aquí se justifica (...adha śyena [iva] javasā nir adiyam), aunque no esté el adverbio "como" (iva) en el texto original, ya que a veces se omite gramaticalmente, tanto por estilo como por ajuste de métrica. Es por ello que asigno el verso sacro 4.27.1 completamente a Indra. En cuanto a los versos sacros 4.26.7 y 4.27.5, son considerados por algunos autores como versos agregados posteriormente (volveré a ello), ya que su significado parece asociarse directamente con una instrucción ritual, es decir, con una acción que forma parte del rito de extracción y ofrecimiento del soma, tal como se conoce a través de fuentes posteriores. 
En la tradición oral védica que se conserva hoy en día se considera muy importante que antes de comenzar la recitación de un himno del Rg Veda, el estudiante declare quién fue el vidente (rsi), cuál es el metro (chandas) y a qué deidad o deidades (devatā) está dedicado el himno. El origen de esta tradición probablemente sea anterior a Yāska (ca. siglo VI a.e.c.), pues en su obra Nirukta toma en cuenta ya estos tres aspectos por separado respecto de cada himno. ${ }^{8} \mathrm{El}$ hecho es que tanto los comentaristas medievales como los traductores modernos han seguido de cerca esta tradición con base en una serie de índices védicos cuya antigüedad dataría de la época de la creación de los aforismos (sütras) y las escuelas védicas (ca. siglo IV a.e.c.). La composición del más general de todos ellos, denominado Sarvānukramanì, dataría de alrededor del siglo II a.e.c. Sin embargo, estos índices no son tan confiables como se quisiera para obtener datos sobre la vida y el arte poético de los compositores del Rg Veda.

En palabras de Witzel:

Lo que los índices Anukramañ̄ realmente conservan, especialmente tratándose de los ciclos familiares (segundo al séptimo), son las atribuciones tradicionales a un clan, o a poetas individuales (reales o míticos), o a poetas que posiblemente asumían el nombre-título de un ancestro real o mítico. En muchas secciones de los ciclos familiares sólo el parentesco de ciertos himnos entre sí es correctamente descrito por el $A n u-$ kramani mientras que los nombres de los poetas involucrados le son desconocidos [...] Es bien sabido que las atribuciones tradicionales de este tipo pueden cambiar con el tiempo [...] Los cambios ocurren en parte cuando un texto originado en una escuela o tradición es cooptado por escuelas rivales posteriores. Esto hace que el uso de atribuciones como éstas sea un extraordinario negocio amañado.

El texto sobre el cual se basa la edición actual del índice Sarvānukramañi más utilizado data de alrededor del siglo v. ${ }^{10}$ Ahí, el vidente de ambos himnos es Vāmadeva o Indra, y el me-

${ }^{8}$ The Nighantutu and the Nirukta of Śrī Yāskāaārya, tr. Lakshman Sarup, Delhi, Motilal Banarsidass, 2009.

${ }_{9}^{9}$ Michael Witzel, "Autochthonous Aryans? The Evidence from Old Indian and Iranian Texts”, Electronic Journal of Vedic Studies, vol. 7, num. 3, 2001, p. 8.

${ }^{10}$ Thennilapuram P. Mahadevan, "The Rṣi Index of the Vedic Anukramañ System and the Pravara Lists: Toward a Pre-history of the Brahmans", Electronic Journal of Vedic Studies, vol. 18, núm. 2, 2011, pp. 11-15. 
tro es trstup, a excepción del verso 4.27.5, que está en el metro śakvari. Y las divinidades adoradas en los primeros tres versos sacros, 4.26.1-3, son ya sea el dios Indra o Paramātmā (indra vā paramātmā). En cuanto al resto de los mantras, 4.26.4-7 y 4.27.1-5, se trata según este índice de un elogio dedicado al Halcón (śyena). ${ }^{11}$ Las otras divinidades involucradas son Agni y Soma.

En la traducción más reciente del $R g$ Veda, Jamison y Brereton indican que ambos himnos se refieren al famoso mito del ladrón del soma ${ }^{12}$ y designan los primeros tres versos, 4.26.1-3, a un discurso de autoalabanza hecho por Indra. Interesante es que, según su opinión, en los versos 4.26.7 y 4.27.2-3 se aludiría a la Plenitud (puraimdhi) deificada, que probablemente habría sido traída desde el cielo al mismo tiempo que el soma. Además, para estos autores, los primeros dos versos, 4.27.1-2, serían un discurso dirigido por el mismo soma.

En su estudio, Knipe afirma: "La exégesis de estos dos himnos es complicada; primero, por la presencia de varias palabras de uso incierto y, segundo, por la dificultad de discernir exactamente quién está hablando y quién está siendo descrito". ${ }^{13}$ El mismo Knipe se centra en el estudio comparado del mito del "ladrón heroico", para quien estaría compuesto por la polaridad simbólica que hay entre el "águila y la serpiente", asociadas a una búsqueda iniciática que, en sus palabras: "está sobre el plano de la reintegración del héroe y revela algo de una estructura iniciática: ascensión, pruebas rigurosas, sacrificio (es decir, muerte simbólica) y, finalmente, renacimiento". ${ }^{14}$

${ }^{11}$ Tanto Karl Friedrich Geldner (Der Rig-Veda, tr. Karl Friedrich Geldner, Londres, Harvard University Press, 1951, vol. 1, pp. 453-456) como Ralph T. H. Griffith (Hymns of the Rigveda, tr. Ralph T. H. Griffith, Varanasi, The Chowkhamba Sanskrit Series, 1963, vol. 1, pp. 428-429) repiten la información de este índice, con la única diferencia de que Geldner interpreta paramātmā como "Indra mismo" y Griffith, como "El espíritu supremo o el alma del universo". Geldner traduce además el himno 4.27 como un diálogo entre el Halcón (4.27.1) y el dios Soma (4.27.2-5). En cuanto a Wendy Doniger O'Flaherty (The Rig Veda: An Anthology, Middlesex, Penguin Books, 1981, p. 128), ella interpreta ambos himnos como el robo del elixir de la inmortalidad, tema similar según esta autora al mito de Prometeo, dado que el soma se considera como un "líquido ígneo".

${ }^{12}$ The Rigveda: The Earliest Religious Poetry of India, tr. Stephanie W. Jamison y Joel P. Brereton, Nueva York, Oxford University Press, 2014, vol. 1, pp. 600-602.

${ }^{13}$ Knipe, “The Heroic Theft”, op. cit., p. 332.

${ }^{14}$ Ibid., p. 355. 
A grandes rasgos, éste es el contenido literal de ambos himnos, del cual partiré para hacer algunas anotaciones relativas a las interrelaciones que hay entre la tradición exegética védica y vedānta acerca de la realización divina.

Como puede apreciarse por lo antes dicho, los autores mencionados asignan el logro de la realización divina declarada en el verso 4.26.1 (aham manurabhavam süryaśca... "Yo era Manu y Sürya...") exclusivamente al dios Indra, y dejan de lado la posibilidad de que aquí se trate de una expresión de autoidentificación con los dioses en boca del vidente que compuso el mantra. En mi opinión, con base en exégesis posteriores y en una elucidación psicológica de las metáforas empleadas aquí, es posible interpretar este verso sacro como la declaración en primera persona de la realización divina lograda por Vāmadeva. Esto sugeriría que al menos un vidente del $R g$ Veda habría declarado de manera simbólica su propia experiencia de realización divina, empleando como recurso la autoalabanza dedicada a un dios que se identifica a sí mismo con todas las deidades, aunada a la imaginería de un ave veloz para expresar un cierto aspecto de esa realización. Para dilucidar esta interpretación puede comenzarse por explorar la referencia a la divinidad suprema hecha por el índice Sarvānukramañi, dado que esta referencia es fundamental para comprender el sentido que comunican los primeros versos sacros de ambos himnos, según las tesis de los comentadores que seguiremos de cerca; a saber, Śańkara y Sāyaṇa.

Como se vio en un párrafo anterior, el índice védico asigna de manera genérica el himno 4.26 en honor ya sea del dios Indra o de Paramātmā (indra vā paramātmāa). Considero que el término paramātmā empleado por el índice Sarvānukramaṇi es una referencia explícita al "supremo sí mismo", una de las expresiones de uso corriente en la época de las upanișads clásicas, equivalente en sentido al de parabrabman, "principio supremo". Me inclino a pensar que los compositores de este índice tenían en mente más bien un concepto utilizado de manera general en el pensamiento filosófico de su época, que un concepto específico relativo a determinada escuela.

Este término no aparece como tal en el $R g$ Veda, por lo que no se podría afirmar directamente que sea de cuño antiguo. Se 
trata de un compuesto de fácil formación que puede emplearse en dos sentidos: "El sí mismo que es supremo" [param-ātmā, adjetivo más nombre igual a compuesto endocéntrico] y "(X) cuyo sí mismo es supremo" [param-ātmā, adjetivo más adjetivo (pronominal) igual a compuesto exocéntrico]. En el texto de concordancias de Lubotsky, el término páram como tal aparece indexado en nueve ocasiones en el $\mathrm{Rg}$ Veda y el término ātmā, en quince. ${ }^{15}$ Estudiar por separado ambos componentes y sus relaciones intertextuales nos alejaría mucho del propósito fundamental de este trabajo. No obstante, es interesante indicar al menos que en algunos mantras (sobre todo de los ciclos tardíos primero y décimo) se menciona la superioridad de una divinidad respecto de las demás; por ejemplo:

El Sol es el sí mismo de todo lo que se mueve y de lo que está estático, ha llenado (con su gloria) el cielo y la tierra, y el espacio intermedio

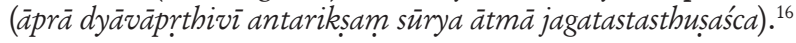

Tu sí mismo es el Viento (ātmā te vātaḅ). ${ }^{17}$

Esta poderosa luz, la mejor de las luces, la más excelente, es llamada "la que conquista todo", "la que conquista riqueza". El Sol, magnánimo, radiante, con la capacidad de iluminar todo, despliega a la vista su vasto poder y su indeclinable vigor (idam śreștham jyotisām jyotiruttamam viśvajiddhanajiducyate brhat. viśvabhrāin bhräjo mahi süryo drśs uru paprathe saba ojo acyutam). ${ }^{18}$

[El Viento] es el sí mismo de los dioses, el embrión del universo. Este dios se mueve según su voluntad (ātmā devānām bhuvanasya garbho yathāvaśam carati deva eșah). ${ }^{19}$

En estos mantras, el término "sí mismo" (ātmā) y la noción de una divinidad por excelencia parecen implicar, en conjunto, la concepción de una divinidad superior cuya esencia es compartida por todas las deidades. Yāska deriva de manera

${ }^{15}$ Alexander Lubotsky, A Rgvedic Word Concordance, 2 vols., Connecticut, American Oriental Society, 1997.

${ }^{16} \mathrm{Rg}$ Veda 1.115.1.

${ }^{17}$ Ibid., 7.87.2.

${ }^{18}$ Ibid., 10.170 .3 .

${ }^{19}$ Ibid., 10.168.4. 
hermenéutica este término a partir de la raíz verbal at, "ir", o āp, “obtener”, y lo glosa como: ["El sí mismo es] 'lo obtenido', en el sentido de que es omnipresente" (ātmātatervā. āptervā. api vāpta iva syāt. yārvad ryyāptibhüta iti). ${ }^{20}$ Cabe mencionar que Śañkara continúa esta misma tradición en su comentario a la Taittirìya upanișad ("El término àtmā se deriva de la raíz āp en el sentido de abarcar todo", äpnoteroyāptikarmanah àtmāa. ${ }^{21}$

Por otra parte, el simbolismo del Sol (Sūrya) empleado para indicar un principio universal es un lugar común en las tradiciones antiguas. En cuanto al Viento (Vāyu, Vāta), éste es un símbolo empleado usualmente para indicar un principio que está en todas partes y es la causa del movimiento. Sin embargo, la concepción más abstracta de esta divinidad de orden superior se halla explícita en el famoso verso sacro: "Los sabios inspirados llaman de muchas maneras a lo Uno (ekam) que es (sat)" (ekam sadviprā bahudhà vadanti), donde claramente se habla de un "dios de dioses", es decir, de un solo principio que es nombrado Indra, Mitra, Varuna, Agni, etcétera..$^{22}$ Sobre este punto tendré la oportunidad de volver a comentar en detalle.

Los primeros versos sacros, 4.26.1 y 4.27.1, de estos himnos son muy importantes ya que son los únicos que se suelen citar parcialmente en las upanisads clásicas y en el resto de la literatura védica y vedānta. Ambos versos tienen en común que están escritos en primera persona. En el Nirukta se dice que cada mantra pertenece a una divinidad en particular, a la cual cada vidente dirige su panegírico con un deseo específico y de la cual se desea obtener su riqueza (yatkāma rsiryasyām devatāyām ärthapatyamicchanstuti prayuinkte tadḋiivatah sa mantro bhavati). ${ }^{23} \mathrm{Y}$, según esta exégesis, los mantras serían de tres tipos: i) los que se dirigen a una divinidad indirectamente; ii) los que se dirigen directamente, y iii) los que son autoinvocaciones.

Este último tipo de versos sacros del R.g Veda son los menos numerosos y emplean el pronombre personal de la primera

${ }^{20}$ The Nighantutu and the Nirukta of Śrī Yāskācārya, op. cit., III.15.

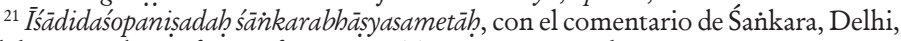
Motilal Banarsidass, s.f. La referencia es Taittirìya upanisad 1.5.2.

${ }^{22} \mathrm{Rg}$ Veda 1.164.46.

${ }^{23}$ The Nighaṇtu and the Nirukta of Śrī Yäskācārya, op. cit., vII.1. 
persona asmad declinado en nominativo singular como parte de su expresión inspirada (atha adbyātmikya uttamapurusayogāh aham iti ca etena sarvanāmnā). ${ }^{24}$ Es interesante anotar además que, según Joshi, en las glosas de Pānini, los comentaristas distinguen entre dos términos idénticos con esta forma "aham": el primero, indeclinable, que se relaciona con el ego, y el segundo, declinable, relacionado con el sí mismo. ${ }^{25}$ Por otro lado, Yāska mismo cita algunos ejemplos de himnos del Rg Veda que están dentro de la categoría de autoinvocaciones; a saber: el himno de Indra Vaikuntha, 10.48; el himno de Lava, 10.119, y el himno de Vāk, la hija de Ambhṛ̣a, 10.125. Creo que es justo agregar ahora a esta selecta lista los himnos de Vāmadeva, 4.26 y 4.27, donde se hace patente la presencia de versos sacros de autoinvocación mediante el empleo de la palabra "yo" (aham).

Esta clasificación también puede sustentarse con apoyo del texto Brhaddevatā. En éste, la variedad de los versos sacros se clasifica en más de treinta según el tipo de alabanza y la majestad que surge de la prominencia natural de una determinada divinidad (mantrā nānāprakārāh syur drștā ye mantradarśibhiḥ. stutyā caiva vibhūtyā ca prabhāvāddevatätmanab). ${ }^{26}$ En otro pasaje se interpreta el pronombre aham, de $\mathrm{Rg}$ Veda 4.26.1-3, como la marca de una autoinvocación donde hay ostentación, es decir, de un himno donde el vidente se alaba a sí mismo como si él fuese Indra o como si Indra fuese él (ahamityātmasamstāvas tṛce stutirivāsya hi [...] indram iva atmānam ṛsis tuștāvend ro vātmānam). ${ }^{27}$

Ahora bien, según el comentario de Sāyaṇa, el significado comunicado por el mantra 4.26.1 es la declaración de la identificación del vidente con la totalidad:

Es dicho que mediante la imaginería de Manu y los demás [dioses] se muestra la realización propia de lo que ha de ser el sí mismo de todo,

${ }^{24}$ Ibid., vII. 2 .

${ }^{25}$ Rasik Vihari Joshi, “The Doctrine of 'Aham-artha”, en Ram Karan Sharma (ed.), Researchs in Indian and Buddhist Philosophy. Essays in Honour of Professor Alex Wayman, Delhi, Motilal Banarsidass, 1993, p. 253. The Astādbyāyĩ of Pānini, ed. Sumitra Mangesh Katre, Austin, University of Texas Press, 1987. La referencia es al aforismo 5.2.140 (abạ̣ śubhayor yus).

${ }^{26}$ The Brhad-devata: Attributed to Saunaka: A Summary of the Deities and Myths of the Rig-veda, tr. Arthur Anthony Macdonell, Delhi, Motilal Banarsidass, 1965, 1.34.

${ }^{27}$ Ibid., 4.135. 
siendo el conocimiento del principio despertado mientras Vāmadeva estaba habitando en el útero. Esto es [lo que se expresa] a través de la [primer] tripleta de mantras y el resto. "Yo", [es decir] Indra o Vāmadeva, "era Manu". Habiendo pensado respecto de todo: "Yo soy Prajāpati”. Yo soy ciertamente Sūrya y también Savitr, el que incita el movimiento de todo. "Sabio inspirado", [es decir], el que posee inteligencia. "Kakșivat", el hijo de Dīrghatamas, yo soy incluso el vidente que tiene este nombre. "Al hijo de Arjuna", [esto es] a Arjuneya, a este vidente que tiene por nombre Kutsa ciertamente yo subyugo, [es decir], hago que esté bajo mi dominio por completo [o también "lo sobrepaso"]. "Poeta", [significa] que su visión sobrepasa. "Ușanas", yo soy ciertamente este vidente llamado así. La declaración [de este mantra] se emplea como una designación analógica [que implica la realización como su objeto elíptico]. Éste es el significado: habiendo visto la verdad suprema [que se expresa como:] "Yo soy Todo", [logré la realización]. ¡Oh, gente!, “¡mírenme!", "a mí", al sí mismo de todo. Ciertamente así ustedes también llegarán a convertirse en su propia naturaleza experimentando aquello que expresa esta declaración. ${ }^{28}$

Cabe destacar que esta identificación con la totalidad que Sāyana da por hecho es tomada en cambio sólo como una suposición por Griffith, justo cuando menciona en sus notas que si Indra se identifica con el vidente Kakșivat es quizás "porque se identifica con todo". ${ }^{29}$ En una sección subsecuente retomaré este tema y mostraré las relaciones exegéticas entre la expresión empleada por el comentarista Sāyaṇa: "Yo soy Todo" (krtsnam abam asmi), para glosar el significado completo del mantra 4.26.1, y el sentido que le da Śankkara a la expresión: "Yo soy Brahman" (aham brabmāsmi), en su comentario a un pasaje de la Bṛhadàranyaka upanișad que se emplea para denotar la realización divina en la filosofía upnishádica. Baste adelantar por el momento que ambas expresiones tienen en común que significan la experimentación plena de una totalidad.

${ }^{28}$ idamādimamtratrayena garbhe vasanvāmadeva utpannatattvajñānạ̣ san sārvātmyam svānubhava manvādirūpeṇa pradarśayannāha. aham vāmadeva iṃdro vā manurabhavam. sarvasya mamtā prajāpatirasmi. aham eva süryaśca sarvasya prerakạ

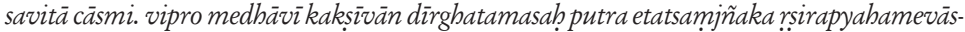
mi. ärjuneyam arjunyāḥ putrạ̣ kutsam etat nāmakam rșim aham eva ny?̣̣je. nitarām prasādhayāmi. kavih krāmẹtadarśi ușanaitadākhya rișirahamevāsmi. uktamupalakșanạ̣. paramārthadrstrtya krtsnam aham asmi iti arthah. he janā mā mām sarvätmakam páśyata. yūyamapyevameva svasvarūpamanbhavatetyuktam bhavati). Rig-Veda-Sambitā: The Sacred Hymns of the Brāhmanas, ed. Max F. Müller, con los comentarios de Sāyānāaārya, Varanasi, The Chowkhamba Sanskrit Series, 1966, vol. 2.

${ }^{29}$ Hymns of the Rigveda, op. cit., p. 428. 
En el segundo verso, 4.26.2, es interesante notar que Sāyana parafrasea el término āryayā por el de mānave. Su traducción es: "Yo di la tierra para Manu", en tanto que la traducción más común, por ejemplo, en Jamison y Brereton, es simplemente: "Yo di la tierra para el Âryo". ${ }^{30}$ En mi opinión, puede conservarse el término àryaya a y traducirlo por "el noble", en el sentido de una persona con cultura y conocimiento. O también, si conservamos la paráfrasis de Sāyaṇa como tal ("mānave", con el aumento vocálico), quizás la traducción más correcta sería: "Yo di la tierra para quien posee la capacidad del pensamiento", derivando el sentido de la raíz man, "pensar". En cuanto a la frase "los dioses se mueven según mi voluntad", recuerda una interesante conexión con un verso del ciclo diez donde la vidente llamada Vāk asevera que ella "camina con los dioses" -cita a los Rudras en primer lugar- $-{ }^{31}$ Recuérdese que este verso es clasificado por Yāska como una autoinvocación.

En el tercer verso, 4.26.3, tenemos dos ideas que son "la embriaguez" y "la destrucción de ciudadelas". La embriaguez se relaciona directamente con el hecho de beber el soma, considerado de manera general tanto el nombre de una planta como su extracto. Pero además este término designa el nombre de un dios. La importancia que tuvo tanto el dios como la planta y su extracto para los compositores del Rg Veda puede apreciarse en el hecho de que se le dedica un ciclo entero a este tema; a saber, el noveno.

El noveno ciclo es uno de los más grandes del Rg Veda, con 114 himnos compuestos por 1108 mantras. Para comprender la importancia del término soma habría que estudiar de cerca los más de 2000 epítetos que, en conjunto, se refieren a las características que se manifiestan en sus formas y poderes especiales, como, por ejemplo: “ $¡ O h$, tú que estás hecho de gotas de néctar!, luminoso, con grandes impulsos, lleno de virilidad, fluye hacia nosotros para obtener las riquezas"; $; 2$ " $\mathrm{O}$ h, purificador!

${ }^{30}$ The Rigveda: The Earliest Religious Poetry of India, op. cit., p. 600.

${ }^{31} \mathrm{Rg}$ Veda 10.125.1. "Yo camino junto con los Rudras y los Vasus y también junto con los Ādityas y Todos los Dioses. Yo sostengo a ambos, Mitra y Varuṇa, a Indra y Agni, a ambos Aśvin" (ahám rudrébhir vásubhiś carāmi ahám àdityaír utá viśvádevaiḥ. ahám mitrávárunobhá bibharmi ahám indrāgní ahám aśvínobhâ).

${ }^{32}$ Ibid., 9.13.3. 
Tú eres el veedor de la región de luz, matas a los que no hacen ofrendas y estás sentado en la fuente de lo recto";3 "El soma se hace consciente al ser purificado en la criba y entonces arriba estruendosamente. Él está sentado mediante su voluntad en la estación de la perfección"; "Soma es éste quien carga [las ofrendas] y está despierto. Que fluyas para quienes desean obtener los dioses"; "Que fluyas extasiado por el gozo con tu corriente a través de la criba. ¡Oh, vidente! Que seas sentado en la fuente de la luz", ${ }^{36}$ etcétera. El estudio de los epítetos que se hallan en éstas y otras frases merecería por sí mismo otro trabajo. Por el momento, baste tan sólo con lo que se ha indicado para darse una idea del rico simbolismo con el que se envuelve el término soma.

Ahora bien, el soma es representado a menudo como una bebida que comparten todos los dioses y los hombres que son sabios inspirados; sin embargo, se dice que es la bebida preferida por Indra y se la relaciona muy estrechamente con él. Las relaciones que hay entre Indra y el soma pueden estudiarse de manera específica, según la perspectiva del vidente Vāmadeva, por ejemplo en el verso 4.17.6, donde se dice que el soma ha existido por siempre en el universo y que por siempre embriagará a Indra, el vasto (satrā soma abhavan asya viśve [...] satrā madāso brhato madișthāh). El soma es el "alimento melifluo" (4.33.3 madhupsarasab). Causa en quien lo bebe alegría y un incremento en el discernimiento y el poder de voluntad (4.37.2 kratve dakșāya harșayanta pitāah). En el verso 4.22 .8 se dice que el soma se libera como un río hecho patente en la energía causada por el trabajo del cantor (śami śáśmānasya śaktiḅ). Según el verso 4.22.1, Indra desea y se deleita en cuatro cosas que el cantor le ofrece: la palabra sabia (brahma), la alabanza (stoma), el soma y la proclamación (uktha). De tal manera que el cantor no sólo tiene derecho al usufructo de la bebida, sino que también mediante su propio esfuerzo puede producirla y ofrecerla desde sí mismo. En este tercer verso, 4.26.3, en particular

\footnotetext{
${ }^{33}$ Ibid., 9.13.9.

${ }^{34}$ Ibid., 9.16.4.

${ }^{35}$ Ibid., 9.3.2.

${ }^{36}$ Ibid., 9.50.4.
} 
se dice que el soma proviene de la "región más elevada", de lo cual se hablará un poco más adelante.

Uno de los focos en la investigación histórica y arqueológica ha sido descubrir la presencia de ciudades en el periodo védico. Al dejar de lado la dimensión sociocultural que esto implica, en el presente trabajo nos centraremos tan sólo en los aspectos metafóricos que puede tener el empleo del concepto de una población grande en la poesía del $R g$ Veda. En el verso 4.26.3 se habla de noventa y nueve "ciudadelas" (purab) más una en especial. La razón para hacer esta división es porque las primeras pertenecen o están bajo el dominio de un demonio (en este caso, Śambara) y la ciudadela que sumaría el número cien es más bien un sitio cuya extensión se hace total o universal. ${ }^{37}$

Pienso que el simbolismo numérico empleado aquí corresponde a la triplicación del número 33 según los tres mundos, para significar la totalidad del dominio que ejercen los dioses en cada plano. El número total de dioses védicos según cierto cómputo es de 33 (la exageración de este número - 33 millones-es un lugar común para decir el número de dioses que hay en el panteón indio) y los tres mundos son la tierra, el espacio intermedio y el cielo; el hecho de que en esta metáfora el halcón irrumpa a través de estas ciudadelas pienso que puede interpretarse como una liberación del aprisionamiento demoniaco ejercido en contra de la luminosidad que es natural a los dioses.

En el verso 4.27.1 se las vuelve a mencionar, pero ahora se especifica su consistencia como "ciudadelas de hierro" (purah àyasīh). Como se verá con detalle en una sección subsecuente, si tomamos en consideración el comentario de Śankkara es posible interpretar las palabras "ciudadelas de hierro" del verso 4.27.1 como una metáfora para referirse a los distintos cuerpos

${ }^{37} \mathrm{Cf}$. el mantra 2.14.6 del Rg Veda: "Oh, ministros, para él, quien, como con un trueno, demolió las cien ciudadelas antiguas de Śambara. Para él, que derrocó a los hijos de Varchin, para Indra, un ciento de miles [de extracciones], ofrezcan el Soma" (adbvaryavo yah śatam śambarasya puro bibhedāśmaneva pūrvīh. yo varcinah śatamindrah. sahasramapà̃vadbharatā somamasmai); también los mantras 9.61.1-2: “¡Ỏ, soma! Que fluyas para el advenimiento [de Indra] en su embriaguez, mediante el cual arrastró las noventa y nueve [ciudadelas]" (ayā vìtī pari srava yasta indo madeșu. ā avāhan navatīḥ nava). "Las ciudadelas fueron alcanzadas [súbitamente]. Śambara fue asesinado en beneficio de Divodāsa, el de intuiciones rectas. Luego así Turvaśa y Yadu” (purạ̣ sadya itthādhiye divodāsāya śambaram. adha tyam turvaśam yadum). 
evocados por la ignorancia que le son falsamente atribuidos al sí mismo (ätman). Para este comentarista, el determinativo "de hierro" implica que la ignorancia mediante la cual subsisten estos cuerpos aparenta ser impenetrable, así como lo que está hecho de hierro. Por lo que el tema común de "la destrucción de las ciudadelas”, y en particular el escape de la deidad en forma de halcón, bien podría referirse al concepto de la liberación gradual desde la perspectiva de la doctrina no dualista.

En su comentario a la Aitareya upanisad, al hacer referencia precisamente a este mantra 4.27.1, Śańkara glosa lo siguiente:

Toda la gente está sumergida en el océano del saṃsāra, transmigrando de este modo, envuelta en la cadena de nacimiento y muerte a través de la manifestación de los tres estados [...] "Un ciento", [esto es] muchas, no sólo una; "de ciudadelas hechas de hierro", es decir, de cuerpos impenetrables como si fueran hechos de hierro; "me guardaron", [es decir] me mantuvieron abajo sin poder soltarme de las ataduras del mundo. ${ }^{38}$

Para continuar, quisiera traer a colación tan sólo tres ideas más recogidas de ambos himnos, 4.26 y 4.27; a saber: la noción de una "región suprema", la ejecución vigorosa de un "movimiento inmediato" de dirección y la "muerte inminente" de los enemigos una vez que se consuma la embriaguez. A excepción de 4.26.7 y 4.27.5, el resto de los mantras que conforman estos himnos (4.26.4-6 y 4.26.2-4) se conectan con el elogio de la gesta del halcón que trae el soma desde "la región suprema", descrita en 4.26.6 y 4.27.4. Esta gesta ha sido comparada por Knipe con algunos temas mitológicos similares del Medio Oriente antiguo. Según este autor, el esquema básico del mito general sería:

I. Un hombre, un héroe, busca una planta mágica.

A. Se presume que la planta tiene poderes de fertilidad (para la concepción, o, en el caso del soma, el jugo sagrado otorga inmortalidad o prolonga la vida).

B. La planta tiene un origen celestial.

${ }^{38}$ evam saṃsāran avasthābhyryaktitrayena janmamaranaprabandhārūdhạ̣ sarvo

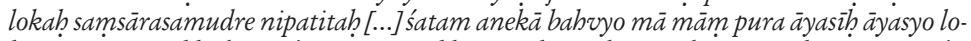
hamanya iva abhedyāni śarīrạni iti abhyprāyah. arakșan rakșitavatyaḥ saṃsārapāśanirgamanāt adhaḥ. Íśädidaśopaniṣadạ̣ śänkarabhāṣyasametāḥ, op. cit. La referencia es Aitareya upanișad 2.1.5. 
II. Un águila lleva al hombre al cielo para obtener la planta.

A. El vuelo involucra una transgresión sobre el reino celeste.

B. Armas vengativas persiguen, pero no matan, al ave transgresora (las flechas de Kṛsánu, los dardos de Šamaš). ${ }^{39}$

Al final de su artículo, Knipe interpreta este mito en términos de muerte y resurrección iniciáticas, sobre lo cual comentaré más adelante. Por el momento, sigamos rastreando las características atribuidas al reino celeste. En el verso 4.21 .3 se le pide a Indra que venga junto con los Maruts desde la región suprema, o desde el mundo de la luz, o desde el soporte de lo recto, para nuestra protección (svarnarāt avase no marutvān parāvato va sadanāt ṛtasya). La región que está más allá (parāvataḅ), del verso 4.26.6, se relaciona con el soporte supremo (paramam padam) que está en secrecía (guba). Según el verso 4.5.12, este lugar supremo es el objetivo que está por encima de todo y se alcanza libre de ataduras (guba adbvanah paramam yanno asya reku padam na nidānā aganma)..$^{40}$ En 4.3.8, Agni, el conocedor de todos los nacimientos, se presenta como un conocedor de este sitio y se le pide que logre el cielo para nosotros (sādhā divo jātavedạ̣ cikitvān); sin embargo, el verso 4.16.9 declara que es Indra quien llega a la presencia del vidente, quien anhela obtener los rayos de luz y la luz celeste ( $g \bar{a}$ abhiștau svarșātā maghavan nādhamānam). Además, este mismo lugar es nombrado, en 4.27.4, como "el mundo de Indra".

Por otra parte, el movimiento inmediato con el cual el halcón fuerza su camino puede compararse con el movimiento de los rayos (arcayaḅ) de Agni que, según el verso 4.6.10, son

${ }^{39}$ Knipe, “The Heroic Theft”, op. cit., p. 344. Este autor presenta, páginas más adelante (ibid. pp. 348-349), una versión extendida de este esquema, que incluye todas las partes del mito que resultarían lógicas en secuencia a partir del método comparativo. Las primeras dos partes de este segundo esquema; a saber: I. "La amistad original, la armonía entre el águila y la serpiente", y II. "Una disputa, pugna entre el águila y la serpiente", no estarían presentes en el relato del $R g$ Veda, pero sí en la literatura india posterior, como en el Ràmāyana, por ejemplo.

${ }^{40}$ Cf. The Rigveda: The Earliest Religious Poetry of India, op. cit., 4.5.12: “¡Oh, Jātavedas!, tú nos has anunciado en secreto la elevada [ruta o paso] de este [ritual] que es nuestro camino, sobre el cual hemos ido, como el de espuelas que anda sobre una ruta vacía”. Estos autores traducen na como el adverbio de comparación. En la traducción que ofrezco traduzco na como la conjunción negativa y el término nidānā como ataduras o cuerdas (véase Sir Monier Monier-Williams, A Sanskrit-English Dictionary, Delhi, Sri Satguru Publications, 2005. 
impetuosos y sonantes como la tormenta y se dirigen a su objetivo como halcones (śyenāso na duvasanāso artham tuvișanaso mārutam na śardhaḅ). Considero que el punto de comparación entre ambos versos es la idea de un movimiento vigoroso y muy rápido, como, por ejemplo, el realizado por grandes aves predadoras, tal como lo es un halcón. En la traducción del verso 4.26.4 que hice arriba, el halcón se describe como: "el de perfectas alas, mediante un carro sin ruedas trae la ofrenda (soma) para los hombres que complacen a los dioses”. Sāyaṇa parafrasea svadhaya acakrayā como cakrarahitena rathena, de donde se obtiene la expresión "carro sin ruedas". La palabra svadha$y \bar{a}$, según algunos autores, significaría "poder propio”, y así es como Knipe traduce esta parte: "porque mediante su poder propio $(s v a d h a y \bar{a})[\mathrm{y}] \sin$ ruedas (acakray $\bar{a})$ el bien alado trajo la oblación amada por los dioses a Manu" ${ }^{41}$

Pienso que la mención de este tipo de vehículos divinos, es decir, las “carrozas”, se utiliza para indicar metafóricamente energías que se ponen en acción; específicamente, energías que comienzan a brillar hasta adquirir un máximo de resplandor. Sabido es que los dioses a menudo son descritos moviéndose en sendas carrozas a través de la órbita solar. En este caso considero que el mantra 4.26.4 se refiere al propio canto vigoroso de un mantra como el medio para acceder a esa región suprema descrita arriba. Hay un breve relato mencionado por Sāyaṇa que quisiera presentar a continuación en apoyo de esta proposición.

Según el comentario de Sāyaṇa, la palabra “ofrenda” (havyam), del verso 4.26.4, sería una metonimia por soma, y esto se conectaría con la leyenda descrita en la Aitareya Brābmana según la cual los dioses y los videntes hacían aquí en el mundo inferior un cónclave:

Soma, el Rey, estaba en el mundo que está más allá. Sobre él, los dioses y los videntes reflexionaron: “¿Cómo vendrá éste a nosotros?". Entonces dijeron a los metros: "Ustedes deben tomar a este Rey Soma para noso-

${ }^{41}$ Knipe, "The Heroic Theft", op. cit., p. 330. Cf. The Rigveda: The Earliest Religious Poetry of India, op. cit., 4.26.4: "Que ese pájaro sobrepase [a todos los demás] pájaros, joh, Maruts!, el halcón de veloz vuelo de entre [todos los otros] halcones, porque el bien alado, mediante su poder independiente que no necesitó [una carroza con] ruedas, trajo a Manu la ofrenda que satisface a los dioses". 
tros". "Sea así" [éstos replicaron], y habiéndose convertido en aves ellos volaron [...] [De entre todos los metros, ni jagatī ni triștubh sino gāyatrī fue quien trajo el soma]. Ella, habiendo volado y habiendo aterrorizado a los guardianes del soma, prensó con el pie y la boca a Soma, el Rey, y también tomó las sílabas que los otros dos metros habían perdido [en su vuelo, al intentar llegar a ese mundo]. [Sin embargo,] Kṛ̛́ânu, un guardián del soma, habiéndole disparado, logró cortar la uña de su pie izquierdo. Ésta se convirtió en un puercoespín. Por lo tanto, éste es como una uña. ${ }^{42}$

Lo importante aquí -además de ofrecernos una explicación inmediata de quién es Kŕ̛áńnu, en el verso 4.27.3- es que por las conexiones que hace el comentador podemos inferir que en su pensamiento hay identidad entre el "halcón" del Rg Veda y el "ave" de la Aitareya Brābmana. Ahora bien, el hecho de que esta última ave sea una transformación del metro gāyātri puede llevarnos a pensar en que su contraparte, el halcón, se manifiesta tangiblemente como el canto de la palabra sabia (brabman) hecho por el vidente que desea autoidentificarse con Indra. Esto es, ambas “aves" van y vienen en su vuelo en dirección al cielo, tal como puede hacerse elevar y descender melodiosamente el tono de un canto. ${ }^{43}$

Pienso que la noción de un movimiento inmediato de dirección es la representación de actividades de carácter mental, como parecen indicarlo explícitamente los términos "veloz como el pensamiento" (manojavas $\bar{a})$, del verso 4.26.5, aplicado al

${ }^{42}$ somo vai rājāmuṣmin loka asìt. tām devāśca rșayaśca abhiadhyāyan kathamayamasmān. te'bruvan chandāmsi. yūyam na imạ̣ somam rājānam āharet iti. tatheti te suparnā bhūtvodapatan [...] sā patitvā somapālān bhīsayitvā padbhyām ca mukhena ca somam gajānam samagrbhnāt. yāni cetare chandasi à àsarānyajahitām tāni copasamagrbhnāt. tasyā anuvisrijya krśánnu somapālạ savyasya pado nakhamacchidat. tacchalyako'bhavat. tasmāt sa nakhamiva. Aitareya Brāhmana, ed. R. Anantakṛṣna Śāstri, con el comentario de Șadguruśsisya, Trivandrum, Bhaskara Press, 1942. La referencia es la sección 3.25-28.

${ }^{43}$ Cito de The Rigveda: The Earliest Religious Poetry of India, op. cit., pp. 22-24: "El producto de la formulación de una verdad, [esto es], la formulación verbal misma, es el brabman, y el poeta que formula esa verdad es el brabman [...] Las verdades que los poetas formulaban eran a menudo verdades secretas, fundadas sobre el enigma y la paradoja. Un tal tipo de verdad era la verdad homóloga que conectaba objetos a través de diversas esferas [...] Los lectores modernos del Rg Veda deben tratar de internalizar las variadas asociaciones e identificaciones que conforman el universo mental inconsciente de la audiencia contemporánea; de otro modo casi cada himno en muchas de sus partes parecerá ininteligible o sin sentido”. 
halcón, y "con la mente velozmente" (astā manasā), del verso 4.27.3, aplicado al guardián del soma. En este sentido, el movimiento inmediato de dirección se relaciona también con el nacimiento del vidente. Según Sāyanaa, se relata la leyenda de que el vidente Vāmadeva, aun al estar en el útero, se rehusó a nacer en la forma usual y resolvió venir al mundo a través del costado de su madre, la que, consciente de este propósito, plegó a Aditi, quien vino en auxilio junto con su hijo Indra.

En el verso 4.18.1, Indra declara sin especificar más que es el camino antiguo y reconocido a través del cual los dioses toman nacimiento (ayam panthā anuvittah purāno yato devā udajāyanta viśve). El siguiente verso, 4.18.2, es una réplica de Vāmadeva, quien dice: "Que venga yo de manera oblicua desde el costado. Muchos actos no ejecutados han de ser completados por mí" (tiraścatā pārśvāt nirgamāni. bahūni me akṛtā kartvāni).

El nacimiento por el costado es un tema recurrente en la descripción de los nacimientos de personajes divinos. En mi opinión, la idea que predomina es la de un nacimiento "contra natura", el cual calificaría en pocas palabras como un nacimiento de orden metafísico provocado por la meditación constante en un pensamiento. Notable es que, según el verso 4.27.3, el recién nacido destruye a sus enemigos desde su nacimiento mismo, así como se tradujo arriba: "Indra en su movimiento asesinó a los enemigos, y entonces estando lleno de fuerza atravesó los vientos (vātān)". Debe recordarse que las batallas entre dioses (devas) y antidioses (asuras) se desarrollan usualmente en la región intermedia, la cual es caracterizada comúnmente por contener los vientos.

Por otra parte, según Śankara, al comentar un pasaje de la Bṛadāranyaka upanișad que será citado a detalle más adelante, a los dioses les disgusta que un ser humano se libere, e incluso pueden, al igual que los demonios, obstaculizar la adquisición del conocimiento de sí mismo en un dado caso. De aquí que el comentador sugiera que alguien que busca la liberación debe ofrendar a los dioses para mantener una buena relación con ellos. Pero más interesante en esta conexión con el verso 4.27.3 es el hecho de que los enemigos son calificados en otro lugar como aquellos que no poseen la palabra de sabiduría (abrabmà dasyub). 
En el verso 4.28.4 se hace una plegaria para que Indra y Soma, juntos, destruyan a los dasyuh, calificados como viśa dāsīh, "gente servil". Aquí Sāyana comenta la glosa del mantra como prajāh karmahināh, es decir, personas que no poseen rituales religiosos instituidos. En cambio, a los poseedores de la palabra sabia, a los sabios cantores védicos, Indra los colma con sus riquezas. Una metáfora común es la de Indra como el distribuidor de riquezas, así como el relámpago que difunde el sonido y la luz en el cielo; por ejemplo, en el verso 4.17.13 (vibhañjanuḥ aśanimān iva dyauḥ uta sotāram maghavã vasau $d h \bar{a} t)$.

Finalmente, en cuanto a los dos últimos versos que hay en cada himno tenemos que, según la observación de Griffith, el mantra 4.27.5 se trataría de un verso adicional por su forma métrica distinta a la de todos los demás y por la evidente instrucción ritual que describe, en tanto que el mantra 4.26.7 es curiosamente elegido por Yāska para comentar sobre el halcón y el sentido ritual de este verso:

El halcón [es llamado así porque] "desciende súbitamente" de manera admirable [...] Habiendo tomado el soma, el halcón lo trajo para un millar, diez millares de libaciones al mismo tiempo. [La palabra] millar es utilizada con referencia al sacrificio, en el cual el soma es exprimido miles de veces. En el sacrificio hay diez millares de tragos, o hay diez millares de obsequios en conexión con la extracción de soma. Ahí el benevolente abandona al enemigo, es decir, al que no es liberal, lo deja atrás en cuanto al deleite del soma, y el sabio deja atrás al lerdo. Él es alabado con referencia a la bebida del soma y en un himno dedicado a Indra. Por lo tanto es identificado con Indra. ${ }^{44}$

En suma, considero que hay conexiones interesantes que permiten interpretar consistentemente ambos himnos como una expresión poética de la realización divina lograda por el propio vidente Vāmadeva, quien además habría descrito de manera metafórica un cierto aspecto de esa realización. En mi

\footnotetext{
${ }^{44}$ śyenah śamsanìyam gacchati [...] ādāya śyeno'haratsomam. sahasram savān. ayutam ca saha. sahasram sahasrasāryamabhipretya. tatrāyutam somabhaks̄āh. tatsambandhenāyutạ̣ dakșiṇa iti vā. tatra purandhirajahādamitrānadānāniti vā made somasya mürä amürah iti. aindro ca sükte somapānena ca stutah. tasmädindram manyante. The Nighantu and the Nirukta of Śri Yāskācārya, op. cit., XI.2.
} 
opinión, el hecho fundamental es que en los himnos $4.26 \mathrm{y}$ 4.27 del Rg Veda hay una declaración, hecha en primera persona, de haber realizado una totalidad, a guisa de una identificación con los dioses y los videntes. Ahora bien, si esta declaración se concibe como expresada al final de una gran hazaña espiritual, entonces, creo, puede hacerse el siguiente análisis esquemático del tenor, el vehículo y el fundamento de los elementos clave de esta descripción metafórica:

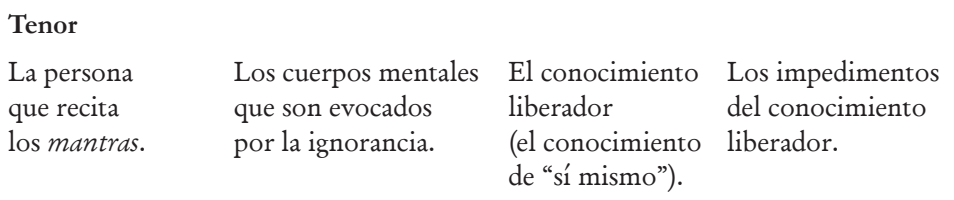

Vehículo

El halcón.

Las ciudadelas.

El soma.

Los enemigos

y los guardianes.

\section{Fundamento}

Ambos se elevan. Ambos aprisionan. Ambos fluyen. Ambos obstaculizan.

Esto es, aquello que se denota mediante el vehículo de las metáforas es una persona que recita los mantras de estos himnos, la cual idealmente se supone que está iniciada en una doctrina espiritual cognoscitiva; a saber, una doctrina que propone la obtención de un conocimiento liberador del ego tras su absorción mediante el constante flujo de la consciencia de sí mismo, libre de impedimentos. Cuando este flujo es sostenido, culminaría en la consciencia de la esencia del ser, lo cual es representado por el hecho de beber una bebida que es de inmortalidad. Esta última metáfora, a saber, la feliz embriaguez provocada por el soma traído desde la región que está más allá, la interpreto como la absorción de la persona en la felicidad máxima, esto es, la plena consciencia de sí mismo. 


\section{Interpretación filosófica no dualista en retrospectiva}

En la sección anterior vimos cómo Sāyaṇa glosa el mantra 4.26.1 para hacer su exégesis acerca de la realización divina, según la cual en este verso hay una expresión de haber alcanzado la totalidad. De manera cronológica, la primera citación de este mantra -junto con el 4.27.1- en un contexto exegético plenamente definido la tenemos parcialmente en textos de la literatura védica tardía, esto es, en las upanișads clásicas (ca. siglos VIII-V a.e.c.). El mantra 4.26.1 también es referido indirectamente por Bādarāyaṇa (ca. siglo II a.e.c.), el compositor de los Brabma sūtras, un compendio de la doctrina filosófica india conocida como vedānta, literalmente, la doctrina que establece "la conclusión (anta) del conocimiento (veda)".

Por otra parte, la escuela vedānta advaita representa la postura más radical respecto a la obtención del conocimiento que se desprende de los textos upanishádicos, es decir, es una postura que lleva hasta sus últimas consecuencias la noción de la identidad entre el individuo (jīva, jī ātman) y el principio supremo (brahman). En esta sección se estudiará en retrospectiva la relación textual que hay entre la literatura canónica del vedānta advaita y el texto del $\operatorname{Rg} V e d a$. De manera específica se hará referencia a la tesis de Śankara (ca. siglo viII) sobre el mantra 4.26.1, según la cual la expresión: "Yo era Manu y Sūrya..." (aham manurabhavam sūryaśca...) es equivalente semánticamente al gran proverbio upanishádico: "Yo soy Brahman" (aham brabmāsmi), que se halla en la Bṛhadāranyaka upaniṣad.

El término upanisad generalmente ha sido interpretado como la denominación genérica para un texto que incluye enseñanzas filosóficas de carácter iniciático. Olivelle traduce este término como "conexión" o "equivalente", debido a que su exposición textual se basa en la proposición de múltiples correspondencias simbólicas; por ejemplo, entre el microcosmo (el ser humano) y el macrocosmo (el mundo)..$^{45} \mathrm{Y}$, según este autor, sería la capacidad de entendimiento de las conexiones secretas lo que le otorga conocimiento, poder, riqueza y presti-

${ }^{45}$ The Early Upanisads, tr. Patrick Olivelle, Nueva York, Oxford University Press, 1998, p. 24. 
gio en este mundo a una persona, además de dicha celestial e inmortalidad.

Las upanisads más antiguas - como la Brhadāranyaka y la Chāndogya- datan alrededor del 800-500 a.e.c. Los orígenes de la doctrina vedānta podrían situarse en el límite próximo de estas fechas, ya que su compendio más antiguo -Brabma sītras (ca. 200 a.e.c.) - refiere tradiciones de maestros y textos antiguos, presumiblemente upanishádicos. No obstante, $\mathrm{Na}$ kamura llama la atención acerca de la superficialidad con la que se estudia de manera general la estrecha relación que hay entre el pensamiento filosófico upanishádico y la doctrina vedānta, como una cuestión pseudohistórica en la que se dejan de lado las diferencias culturales de cada época, además de las variaciones en el pensamiento filosófico, sobre todo respecto de la interpretación advaita de Śańkara acerca de las upanișads, hecha por lo menos con mil años de retrospectiva. ${ }^{46}$

La doctrina advaita, como su propio nombre lo indica, es una postura metafísica que niega (a-) toda aquella dualidad (dvaita) que pueda ser postulada o concebida. Tómese, por ejemplo, la dualidad postulada por la escuela samkbyā entre purusa y prakrti, o bien la dualidad concebida por una persona cualquiera entre su "sí mismo" y el "sí mismo" de otra persona. La doctrina no dualista niega que haya dos principios o dos seres cualesquiera concebidos racionalmente que sean independientes. Específicamente, proclama la no diferencia entre ātmān y brabman.

El término filosófico brabman designa la concepción abstracta de un principio supremo definido como: ekam eva advitizyam; literalmente, "uno-sin-segundo" (es decir, "absoluto", que no entra en contacto o en relación con alguna cosa). Ahora bien, cuando a brabman no se le considera como un principio supremo, sino más bien como un principio universal, se le designa como àtman; literalmente, "sí-mismo" (es decir, "la cosa propia de sí”, lo que funciona como el pronombre reflexivo que sustituye a brabman en todos los casos). Desde este último punto de vista, brahman se manifiesta a sí mismo, por sí mis-

${ }^{46}$ Hajime Nakamura, A History of Early Vedānta Philosophy, Delhi, Motilal Banarsidass, 1983, p. 114. 
mo y en sí mismo. Es decir, desde la perspectiva de lo manifestado, brabman es el àtman que reside en el corazón de todos los seres (esto es, en la parte más interior de cada uno). El propósito final de esta doctrina es que un estudiante calificado (adhikārin) se libere a sí mismo de cualquier atadura o condicionamiento.

Potter señala 18 puntos que caracterizan las bases teóricas del vedānta advaita. ${ }^{47}$ En resumen, la doctrina no dualista es una instrucción iniciática cuyo objetivo final es demostrar que la experimentación de la dualidad es un estado de consciencia ilusivo oscilatorio, donde no hay realmente consciencia del sí mismo; de hecho, la no consciencia del sí mismo es lo que se manifiesta como el universo que se idea, se percibe y se siente, actividades que provocan por sí mismas una especie de atadura en cada persona. Lograr la liberación (mokșa) de esta "atadura” es el propósito final de la instrucción.

La liberación sería en primera instancia un asunto de conocimiento (jñana), dado que sólo éste puede erradicar la ignorancia $(a v i d y \bar{a})$ que es la causante de la atadura al universo. Además, la ignorancia es la causa de que se experimente un ego (ahamkāra) que oscila entre la alegría y el sufrimiento. En cambio, el conocimiento que destruye por completo la ignorancia es denominado específicamente el "conocimiento de sí mismo" (àtmājñana), el cual hace patente a una persona su identidad con el principio supremo. La médula de esta doctrina estribaría en afirmar, por un lado, que el sí de cada sí mismo individual (jīva, jīvātman) es idéntico al sí mismo (ātmān), y, por el otro, en negar que el sí mismo (ātmān) se distinga realmente del principio absoluto (brabman), sino sólo por medio de las limitaciones adjuntas (upādhi) creadas a la vez como causa y efecto de la ignorancia (avidyā).

De manera general, en las upanișads clásicas se hace referencia a hombres de conocimiento procedentes de distintas clases sociales como los transmisores de las doctrinas que son enseñadas ahí a través de coloquios e ilustraciones, pero también se hace referencia a ciertos dioses (devas) y a algunos vi-

${ }^{47}$ Karl H. Potter, Advaita Vedānta up to Śamkara and His Pupils, Nueva Jersey, Princeton University Press, 1981, pp. 6-9. 
dentes. Una de estas doctrinas upanishádicas es precisamente aquella de la realización divina, es decir, la doctrina que expone la identificación personal con los dioses y sus poderes como el fruto de la constante meditación en ellos, y, muy a menudo, se hace referencia a un personaje en particular como el ejemplo de alguien que, en el pasado, hubo logrado esta realización. En este sentido, el vidente védico Vāmadeva es citado por su nombre en la Bṛhadāranyaka upanișad y la Aitareya upanisad. ${ }^{48}$

Es evidente que los compositores de las upanisads clásicas (ca. siglos vIII-V a.e.c.) buscaban con esto anclarse a la tradición védica (ca. siglo XII a.e.c.). Esta misma estrategia de legitimación fue utilizada por Bādarāyaṇa (ca. siglo II a.e.c.), el compilador de la doctrina vedānta, quien también citó a Vāmadeva en su obra Brahma sūtras. ${ }^{49}$ Hasta qué punto el simple hecho de insertar citas textuales implica una continuación del espíritu de la tradición védica temprana en la tardía, o hasta qué punto implica ello la reiteración de ideas metafísicas antiguas en los comentaristas posteriores, son cuestiones que están sujetas a la discusión y el debate. A continuación se ofrece una síntesis de estos pasajes apenas señalados - junto con los comentarios de Śankara- para explorar, a través de su conexión textual con el Rg Veda, el proceso de apropiación de ideas. guiente:

En un pasaje de la Bṛhadāranyaka upanișad se lee lo si-

Brahman era ciertamente este [sí mismo] en el principio. Eso se conoció sólo a sí mismo de esta manera: "Yo soy brahman". Por ende, Eso llegó a ser Todo. Y cualquiera de entre los dioses que despertó el conocimiento de Eso, ése también llegó a ser Eso; asimismo entre los videntes, asimismo entre los humanos.

El vidente Vāmadeva mientras veía que Eso es este [sí mismo] llegó a conocer [el mantra]: "Yo era Manu y el Sol, etcétera". Y quienquiera al

${ }^{48}$ The Bṛhadāranyaka Upanișad, tr. Swami Madhavananda, con el comentario de Śan̉karācārya, Kolkata, Advaita Äshrama, 2004. La referencia es Bṛhadāranyaka upanisad 1.4.10. Íśádidaśopaniṣadạ̣ śánkarabhāsyasametāh, op. cit. La referencia es Aitareya upanisad 2.1.5.

${ }_{49}^{4}$ The Brahmasūtra-Śánkara-Bhāsya, ed. E. A. Soloman y K. L. Joshi, con los comentarios Bhāmatì, Kalpataru y Parimala, Delhi, Parimal Publications, 1982, vol. 1. La referencia es la sección 1.1.30. 
presente que también conoce que Eso es este [sí mismo], de esta manera:

"Yo soy brahman", ése llega a ser este Todo.

Para la escuela vedānta advaita esta importante sección incluye uno de los llamados grandes proverbios (mahāvākyas) que concluyen el propósito de la instrucción no dualista acerca del principio supremo. La declaración "Yo soy brabman" (aham brabma asmi) expresa el hecho de haberse identificado plenamente con brabman tras la realización del conocimiento de sí mismo (ätmājñāna). Este hecho conlleva como una consecuencia consustancial la erradicación de la ignorancia y, por ende, la erradicación del universo -en sus tres aspectos: inteligible, perceptible y sensible- ya que su base es una mera realidad convencional (vyāvahārika). Los compositores de esta upanișad mencionan a Vāmadeva como el ejemplo de un conocedor de brahman y hacen la cita parcial del mantra 4.26.1 del $R g$ Veda adjudicado a él.

Nótese que en este pasaje upanishádico la realización divina es definida explícitamente como darse cuenta de que uno mismo es el principio supremo y que esto se presenta como algo asequible para cualquiera, ya sea un dios, un vidente o un humano. En su comentario, Śankkara argumenta contra el punto de vista según el cual la liberación obtenida mediante este conocimiento es algo que sólo habría sido posible para personas poderosas que se manifestaron en el pasado. El comentarista responde que cualquiera que refrene su interés por las cosas externas en cualquier momento y conozca su sí mismo interior como el principio que ha entrado y está en todos los seres -el cual es indicado mediante las funciones de la visión, escucha, etcéterapuede lograr la realización divina.

En suma, para Śañkara, cualquiera que llegue a ser un estudiante calificado (adhikärin) con los cuatro requisitos previos al estudio de la doctrina vedānta, a saber: discriminación (viveka), renunciamiento (tyāga), los seis tesoros del ascetismo (śama,

\footnotetext{
${ }^{50}$ brahma vā idam agra āsìt tat ātmānam eva avetam - aham brahma asmi iti -. tasmāt tatsarvam abhavat. tat yo yo devānām pratyabudhyata sa eva tat abhavat tathā rssin̄ām tathā manusyānām. tat ha etat paśyan rssị̣ vāmadevaḥ pratipede - aham manurabhavam süryah ca iti. tat idam api etarbi ya evam veda aham brabma asmi iti sa idam sarvam bhavati. The Bṛhadāranyaka Upanișad, op. cit. La referencia es Bṛhadāranyaka upanișad 1.4.10.
} 
dama, uparati, titikșā, samādhāna y śraddhā) y el intenso deseo de liberación (mumukștvam), puede llegar a conocer su sí mismo como "Yo soy brahman":

Porque no hay diferencia respecto a brabman o al conocimiento de Eso entre los humanos, ya sean poderosos como Vāmadeva y los demás [conocedores del pasado] o débiles como los de hoy en día. ${ }^{51}$

Otro punto notable de este pasaje de la Brhadāranyaka upanișad es la expresión "en el principio" (agre), con la que se hace referencia a la instrucción según la cual todo este universo manifestado se concibe como algo preexistente en un solo punto atemporal; es decir, como algo preexistente de manera germinal, en un estado latente e indiferenciado. En otras palabras, solamente al manifestarse el universo es cuando se presenta como un efecto compuesto de nombre, forma y acción, que se despliegan; sin embargo, este mismo efecto permanece siempre indiferenciado en tanto que una causa situada en el principio. Luego entonces, sólo quien se autoidentifica con brahman - principio supremo y la causa única del universo- conoce que "todo esto" (sarvam idam, el universo) es únicamente el sí mismo (ātman), antes y después de diferenciarse en el tiempo y el espacio.

Revisemos ahora el pasaje de la Aitareya upanișad, donde se lee lo siguiente:

Ese [hecho] fue declarado por el vidente:

"Aun estando en el útero, yo conocí los nacimientos de todos los dioses. Una centena de ciudadelas de hierro me guardaron. Ahora, como un halcón, forcé mi salida con el vigor”.

Así declaró este [vidente] Vāmadeva [estando] contraído aún en el útero. ${ }^{52}$

${ }^{51}$ na hi mahāvīryeșū vāmadevādisu hinavirryeșu vā vārtamānikeșū manusyeșu brahmano viśeșạ tadvijiñanasya vāsti. İdem.

${ }^{52}$ tat uktam rșinā-garbhe nu san anu eșām avedam aham devānām janimāni viśvāa śatam mā pura āyasīh arakșan adhạ̣ śyeno javasā niradīyam iti -. garbhe eva etat śyāno vāmadeva evam uvāica. İ́ädidaśopanișada ș śänkarabhāṣyasametāḥ, op. cit. La referencia es Aitareya upanisad 2.5. 
El contexto que precede esta cita es la descripción de los tres nacimientos o estados en los que se manifiesta el sí mismo durante su transmigración en un cuerpo tras otro. El primer estado es el nacimiento del sí mismo como semen del padre; el segundo es el nacimiento del sí mismo como hijo de la madre, y el tercero, el nacimiento que obtiene el "padre" después de su muerte. La idea es que tanto el padre como el hijo actuales son en realidad idénticos, por lo que a cada uno, en su turno, le tocará convertirse a su vez en el "padre" que obtiene un tercer nacimiento inmediatamente después de su deceso. En este pasaje se cita parcialmente el mantra 4.27.1 del Rg Veda, donde Vāmadeva declara que conoció el nacimiento de todos los dioses aun estando en el útero (garbha), en el interior de la madre, formando un solo cuerpo con ella. Y la leyenda del halcón - descrita en la primera parte de este estudio- que se libera y se va hacia la región suprema en busca del soma, aunque no es aquí mencionada, debió sin duda haber sido algo consabido de manera implícita.

Śankara comenta aquí que el vigor con el cual el halcón forzó su salida es el vigor que se obtiene gracias al conocimiento de sí mismo. Śankkara comenta que la metáfora del halcón que irrumpe con fuerza hacia arriba para escaparse de las distintas ciudadelas es una imagen del practicante que se libera de las ataduras a los distintos cuerpos: ${ }^{53}$

“Él”, el vidente Vāmadeva. "Habiendo conocido así”, conociendo el sí mismo como se indicó previamente. "Después de la destrucción de este cuerpo", de este cuerpo que es evocado por la ignorancia [...] En el momento de la disolución de las ataduras de los cuerpos, sujetos a cientos de males multifarios que consisten en nacimiento, muerte, etcétera. "A través del poder generado por la degustación del néctar del supremo sí mismo", es decir, con la destrucción del cuerpo que prosigue de la destrucción de causas tales como la ignorancia que son las semillas de la creación del cuerpo. "Él se elevó", estando identificado con el supremo sí mismo. ${ }^{54}$

${ }^{53}$ Idem. sa evam vidvān asmāt śarīrabhedāt ūrdhva utkramya amuṣmin svargaloke sarvān kāmān aptvā amrtah samabhavat samabhavat.

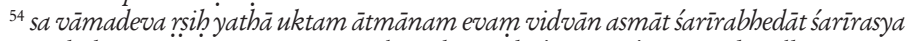
avidyāparikalpitasya [...] jananamaranādyanekānarthaśatāviștaśarìra prabandhasya para-

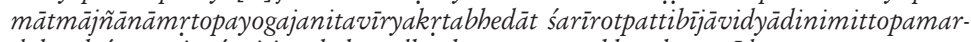
dahetoḥ śarīravinäśät iti arthah. ürdhvah paramātmabhütạ san. Idem. 
Nótese que la metáfora de atravesar las "ciudadelas de hierro" (āyasīh puraḥ) utilizada en estos himnos védicos es empleada, según Śańkara, para referir el despojo de los cuerpos que toma el sí mismo durante su transmigración. Porque se dice que estos cuerpos son evocados por la ignorancia, la cual es impenetrable como el hierro. Y que la adquisición de un cuerpo es precisamente la causa de cientos de males, tales como el "nacimiento", la "muerte", etcétera. La conclusión de este comentario es que el vidente, una vez que obtuvo la realización divina, llegó a ser inmortal (amrtaḅ), y habitó desde entonces en el mundo celeste (svarge loke), lo cual es interpretado por Śankkara como habitar en su propio sí mismo (svasmin àtmanisve).

Es interesante destacar además que Śañkara, en su prefacio al capítulo III de la Aitareya upanișad, considera a Vāmadeva como parte de la sucesión de maestros tradicionales, y que vuelve a mencionar aquí explícitamente la posibilidad de la liberación para cualquier estudiante calificado en cualquier momento:

Hay algunos brāhmanās [estudiantes tradicionales] contemporáneos que se esfuerzan por la liberación, que anhelan el conocimiento de brabman, y se dan cuenta de que el logro de la identidad con el sí mismo de todo se sigue de las disciplinas del conocimiento de brabman, tal como han sido reveladas por los Vedas a través de la sucesión de maestros como Vāmadeva y los bien conocidos en las asambleas de los conocedores de brahman. ${ }^{55}$

Finalmente, tenemos el pasaje de Bādarāyaṇa, el aforismo de los Brahma sūtras, el cual, presumiblemente, hace referencia a la tradición védica de los himnos. En este aforismo se lee lo siguiente:

Sin embargo, la instrucción [dada se justifica] a través de la intuición que ha sido mostrada por el texto preceptivo, como en el caso de Vāmadeva. ${ }^{56}$

${ }^{55}$ brahmavidyāsādhanakrtasarvātmabhāvaphalāvāptim vāmadevādyācāryaparamparayā śrutyāvadyotyamānām brahmavitparișadi atyantaprasiddhām upalabhamānā mumuksavo brāhmañā adbunātanā. Idem.

${ }^{56}$ śästradrsțtyā tu upadeśạ vāmadevavat. The Brahmasūtra-Śä̀nkara-Bhāsya, op. cit., 1.1.30. 
Esta oración coordinada adversativa forma parte de un conjunto de cuatro aforismos de los Brabma sütras que hacen referencia a un pasaje de la Kauśitaki upanișad donde Pratardana le pide al dios Indra que le declare cuál es el mejor de los dones. ${ }^{57}$ Indra termina dándole la siguiente instrucción:

"Conóceme sólo a Mí", esto es lo que considero el mejor de los bienes para los seres humanos [...] Yo soy la fuerza vital, el sí mismo que consiste en sabiduría. ${ }^{58}$

La cuestión que se debate aquí es, por un lado, si el término "fuerza vital" (präna) puede ser interpretado como un referente más en las upanisads del principio supremo (brabman), tales como "éter" (äkāśa), "luz" (jyotis), "ser interior" (antah), etcétera, $y$, por el otro, si la instrucción dada por Indra implica que éste se identificó a sí mismo con brabman.

El aforismo pränạ tathā anugamāt establece que el concepto de la "fuerza vital" denota asimismo el principio supremo según los textos preceptivos transmitidos. ${ }^{59} \mathrm{Y}$ aunque brabman es presentado en este pasaje de la upanișad como el prāna, debido a las características que son descritas ahí ("el sí mismo que consiste en sabiduría", "inmortal", "indestructible", etcétera), se debe llegar a la conclusión de que no se trata de la fuerza vital solamente, sino del principio supremo, concebido específicamente como el principio universal de la vida. Por su parte, el aforismo na vaktub ätmopadeśát iti cet adbyātmasambandhabhīmā hi asmin refuta la objeción de que el interlocutor que nos presenta la upanișad, esto es, Indra, se refiera a sí mismo como un dios personal, debido a que hay una abundancia de referencias al sí mismo interior y a la realización del conocimiento de brabman en todo el pasaje de la Kauśitaki upanișad. ${ }^{6}$

Por último, respecto del aforismo de los Brahma sūtras citado arriba, la interpretación del comentarista es que aquí se hace referencia a que el dios Indra se identificó a sí mismo con

${ }^{57}$ Ibid., 1.1.28-31.

${ }^{58}$ māmeva vijänīhi etadevāham manusyāya hitatamam manye [...] praṇo'smi prajñātmā. İ́ádidaśopanișadah śánkarabhāsyasametāh, op. cit.

${ }^{59}$ The Brahmasütra-Śä̀nkara-Bhäsya, op. cit., 1.1.28.

${ }^{60} \mathrm{Ibid} ., 1.1 .29$. 
el principio supremo (param brahma), según la instrucción del texto preceptivo "tú eres eso" (tat tvam asi). Y mediante dicha instrucción habría surgido en él la misma intuición que tuvo el sabio Vāmadeva cuando se dio cuenta de que su sí mismo era el supremo sí mismo. Debido a ello, lo que el vidente expresó como: "Yo soy Manu y el Sol, etcétera", se expresa también en la instrucción dada por el dios Indra a Pratardana de esta manera: "Conóceme sólo a Mí". ${ }^{61}$

En suma, el vidente védico Vāmadeva, compositor principal del cuarto ciclo del Rg Veda, es citado en la literatura upanishádica como el ejemplo por antonomasia de alguien que logró en sí mismo la realización divina. Quienes hayan sido los compositores de las upanișads clásicas hicieron manifiesto con ello que la tradición védica temprana continuaba siendo una autoridad prestigiosa para ellos y se presentaron así, bajo esta estrategia, como sus legítimos continuadores en la época védica tardía. Posteriormente, Bādārayaṇa, el compositor de los Brabma sūtras, utilizó en su compendio canónico de la doctrina vedānta la referencia a Vāmadeva como una ilustración ad hoc de un conocedor de brabman. Luego, Śan̉kara se apropió de esta tradición arraigada sobre la cual comenta y abunda.

Pienso que a partir de estas citas puede formularse lo siguiente respecto a la relación que hay entre la tradición védica y la tradición vedānta (específicamente con la doctrina advaita patente en los comentarios de Śañkara) por un lado, y entre el $R g$ Veda y las upanișads, por el otro: i) es evidente que Śañkara se refiere a algunos videntes védicos como conocedores de brahman en el mismo sentido en que él lo entiende, y por ello los considera de manera acrítica maestros predecesores de la doctrina filosófica no dualista que él reformuló; ii) el contenido filosófico de las upanișads se considera un desarrollo especulativo posterior al $R g$ Veda, específicamente, un desarrollo de ciertas ideas metafísicas de las que habría ya algunas muestras en el ciclo más tardío; a saber, el décimo; sin embargo, es probable que en la misma tradición oral original hayan coexistido

${ }^{61}$ indro nāma devatātmā svam ātmānam paramātmatvena aham eva param brahma iti rșeña darśanena yathāśästram paśyan upadiśati sma - mām eva vijānīhi - iti. yatha 'tä ha etat paśyan rssị̣ vāmadevah pratipede - aham manurabhavam sūryaśca - iti tadvat. Idem. 
tanto la recitación de himnos que expresan un conocimiento litúrgico de alabanza, como la de himnos que expresan un conocimiento liberador, similar en contenido al que es expresado en las partes nucleares de las upanișads, y iii) es posible que haya una antiquísima línea de maestros y comentadores védicos que interpretan ciertos mantras e himnos del $\mathrm{Rg} \mathrm{Veda}$ como textos que revelan el conocimiento del principio supremo (brabman).

En la introducción a su comentario a la Bṛhadāranyaka upaniṣad, Śankkara distingue de manera tajante entre la porción del Veda que está relacionada con la acción ritual (karma-khanda) y la porción relacionada con el conocimiento (jñana-khandia); sin embargo, no hay indicios de que identifique el $\mathrm{Rg} V$ Veda tan sólo como un texto relacionado con el karma. De hecho, las pocas citas que retoma de éste se insertan en un contexto relativo ya sea a la meditación o al conocimiento. Hemos visto cómo comenta él las citas que involucran los mantras 4.26 .1 y 4.27 .1 a favor de la doctrina vedānta advaita. Empero, Śañkara recurre al $\mathrm{Rg}$ Veda no sólo en éste sino en varios contextos en busca de una cita con la cual legitimar su propia exégesis. ${ }^{62}$ Por ejemplo, al comentar el verso I.4.6 de la Bŗhadāranyaka upanișad, cita el mismo mantra que Sāyaṇa ( $\operatorname{Rg} \dot{V}$ eda 1.164 .46 , véase el siguiente párrafo) en su introducción al $R g$ Veda, para establecer que, en el plano de los dioses, el Dios Creador (Virāj); en el plano cósmico, el Embrión de Oro (Hiranyagarbha), y en el plano personal, el sí mismo individual (jî̀ūtmā), son en realidad el supremo sí mismo (paramātmā), aunque la mayoría de las veces sean descritos como seres con limitantes y con carácter transmigratorio.

Finalmente, me parece crucial señalar el hecho de que Sāyaṇa, además de ser el intérprete por antonomasia del $\operatorname{Rg} \mathrm{Veda}$ en clave ritual, también forma parte de una tradición vedān-

${ }^{62}$ Cito de Natalia Isayeva, "Shankara and Indian Philosophy", Nueva York, State University of New York Press, 1993, p. 237: "Los textos de la sagrada escritura (Veda) no representan ninguna adición innecesaria para el Advaita; éstos no pueden ser mirados como un tributo al tiempo o, en las palabras de Deussen, un tributo a los prejuicios nacionales. La constante referencia a estos textos y la confianza bien enraizada que descansa en el lenguaje de la śruti emergen en última instancia de las regularidades internas de las enseñanzas de Śan̉kara, a partir de sus principales argumentos”. 
ta cuya concepción filosófica parece ser más de carácter monista que no dualista. Sāyaṇa declara al principio de su comentario al $R g$ Veda que todos los sacrificios que son celebrados se ofrecen solamente para un dios supremo (parameśvarāt yajñāt yajanìyāt püjanīyàt sarvahutah sarvairhūyamāt), además de que introduce el término aikya (unicidad), el cual parece ser la base de su interpretación àtmika (relativa al sí mismo) del $R g$ $V e d a$. Cita en apoyo de su tesis el mantra 1.164.46, según el cual todos los nombres divinos son tan sólo nombres de un dios supremo (indram mitram varunamagnimähuratho divyạ sa suparno garutmān. ekam sädviprā babudhà vadantiagnim yamạ̣ màtariśvānamāhuh). ${ }^{63}$ Sāyana interpreta aquí el pronombre "él”, sah, como referido al "Ėl Sol” (sūryaḅ), y glosa: "El dios Sol es ciertamente el único gran sí mismo" (ekaiva vā mahān ātmā devatā sūryaḥ). ${ }^{64}$ Él hace estas observaciones en el contexto de la discusión sobre cuál Veda debe ser comentado primero, si el Rg Veda o el Yajur Veda.

Se decide a favor del Yajur Veda dado que éste trata con la ejecución de los sacrificios directamente, y el propósito general de sus comentarios es exponer el significado ritual desde el punto de vista yājñika (relativo al sacrificio). Sin embargo, Sāyaṇa mismo admite la interpretación del $R g$ Veda relativa al sí mismo para algunos mantras e himnos completos. De hecho, todo su comentario al himno 1.164 está hecho bajo las premisas más generales de la escuela vedānta. En palabras de Pandurangi:

[Sāyaṇa, a pesar de partir de un punto de vista ritualista...] no niega el hecho de que los himnos del $\mathrm{Rg}$ Veda comunican un dios supremo ( $p a-$ rameśvara), que los nombres de las divinidades comunican un dios supremo, y que las ofrendas a las diferentes divinidades son ofrendas para un dios supremo. Si esto es entendido sobre la base de la antaramitva

${ }^{63}$ Yāska es el primero del que tenemos noticia en haber comentado este mantra en The Nighantu and the Nirukta of Śrì Yäskācārya, op. cit., vII.18: "Ciertamente los inteligentes llaman variadamente a este Agni, el gran sí mismo. [Lo llaman] Indra, Mitra, Varuna, Agni y el divino Garutmān. 'Divino', esto es, nacido en el cielo. 'Garutmān’ es llamado así porque es alabado, o porque es el poderoso sí mismo, o el gran sí mismo" (imamevāgnim mahāntam ātmānam bahudhā medhāvino vadanti. indram mitram varunamagniṃ divyam ca garutmantam. divyo divijạ̣. garutmān garanavān. gurvātmā. mähātmeti vā.).

${ }^{64}$ Rig-Veda-Sambitā: The Sacred Hymns of the Brähmanas, op. cit. 
(inmanencia) de la divinidad o sobre la identidad de la divinidad suprema y otras divinidades eso es una cuestión distinta. ${ }^{65}$

Por tanto, me parece que este autor también admite la realización divina como una autoidentificación con un dios supremo.

\section{Notas finales}

En este trabajo se presentó una traducción de los himnos 4.26 y $4.27 \mathrm{del} R g$ Veda y se hizo un estudio de ambos centrado en la noción de la realización divina, la cual es, según la tradición exegética védica y vedānta, sugerida por el vidente védico Vāmadeva bajo la forma de autoidentificación con los dioses y los videntes. Después se rastreó una línea de interpretación textual del $R g$ Veda que conecta específicamente los mantras 4.26.1 y 4.27.1 con la Bṛhadāranyaka upaniṣad y la Aitareya upaniṣad, textos que forman parte de la literatura canónica upanishádica y del vedānta respectivamente. En particular, respecto de la escuela vedānta, se rastreó también una importante cita de los Brabma sūtras. Los puntos que se hicieron resaltar fueron que, según los comentarios de Sāyaṇa, esta realización implica una identificación con el Todo (sarvam), mientras que, según los comentarios de Śan̉kara, la realización divina expresada por este vidente es la misma experiencia que logra un conocedor de brabman, la cual implica la liberación de los cuerpos evocados por la ignorancia.

La mayoría de los académicos citados en este trabajo concuerdan en asignar la realización divina sugerida en ambos himnos tan sólo al dios Indra, esto es, como un motivo puramente eulogístico; en tanto que algunos están dispuestos a interpretar el contenido de estos himnos en términos de una leyenda iniciática. En este sentido, destaca Thompson, quien argumenta de manera convincente que los himnos de autoalabanza (ātmastuti, 10.125., 4.26, 4.42, etcétera) representan en realidad un medio de autoafirmación e impersonificación de los poetas, para con-

\footnotetext{
${ }^{65}$ Rig Bhashya of Sri Madhvacharya, introducción de K. T. Pandurangi, e-book publicado por tatvavada.org, p. 9.
} 
cluir que: "[El] poeta del $R g$ Veda al ejecutar un àtmastuti está adoptando la persona de un dios y mediante ello puede decirse legítimamente que es un 'dios humano', tal como se predica de un brabmin en Śatapata Brähmaña 2.2.2.6”. ${ }^{66}$

Mi conclusión es que la realización divina sugerida por Vāmadeva en ambos mantras es precisamente la manera como él hace una descripción poética de su experiencia personal de reintegración a la consciencia de totalidad. Me inclino a pensar que esta consciencia de totalidad era originalmente interpretada en los Vedas como la reintegración a la unidad brillante de un solo dios, por lo que pienso que las tesis monistas de Sāyana son más aptas para interpretar estos himnos, en tanto que las tesis netamente no dualistas de Śankkara difícilmente tendrían su origen en el pensamiento védico temprano. Lo que es claro es que este último comentarista buscaba legitimar su discurso al anclar su propia doctrina en el texto mismo del Rg Veda.

A este respecto, cito de Halbfass:

Hay patrones de mitología védica, tales como sus esquemas recurrentes de inmanencia-en-trascendencia, o de unidad-en-diversidad, los cuales llegaron a ser precedentes y presuposiciones del pensamiento filosófico. Hay, sobre todo, aquellas enseñanzas elusivas, aun así distintas y sugestivas, respecto al àtman y el brabman que pensadores tales como Bhartrhari y Śankara intentaron recuperar como una anticipación de su propio pensamiento y como una respuesta primigenia al reto budista. ${ }^{67}$

No obstante, quiero destacar que, al menos textualmente, la realización divina sugerida por Vāmadeva en el $R g$ Veda es interpretada tanto por Śankara como por Sāyana de manera muy coherente, bajo la premisa de un "principio supremo" (brabman) y de un "dios supremo" (parameśvara) respectivamente. Si aceptamos, según lo dicho apenas, que las tesis de Sāyana son más aptas para reflejar la filosofía védica, en tanto que las de Śankara al final de cuentas descansan sobre premisas upanishádicas, entonces quizás la gran diferencia respecto de los periodos

${ }^{66}$ George Thompson, "Ahamkāra and Ātmastuti: Self-Assertion and Impersonation in the Rgveda”, History of Religions, vol. 37, núm. 2, noviembre de 1997, p. 171.

${ }^{67}$ Wilhelm Halbfass, Tradition and Reflection: Explorations in Indian Thought, Nueva York, State University of New York Press, 1991, p. 40. 
del pensamiento védico temprano y tardío es que la doctrina de la realización divina es elaborada en términos teístas en el $R g$ Veda, mientras que en las upanisads se emplean términos filosóficos impersonales. En otras palabras, en el $\mathrm{Rg}$ Veda se recurre a la imaginería de los dioses, sus poderes y sus actos en diversos planos divinos, para sugerir la realización divina, en tanto que en las upanișads se recurre, más allá de las conexiones que proponen, a la constante mención de un solo principio que se autoidentifica consigo mismo. Y pienso que ambos comentaristas continuaron ampliando el sentido de estos mantras estudiados en una misma línea de interpretación monista que deriva finalmente en el absolutismo.

De acuerdo con Gonda, uno de los autores más comprometidos con el estudio del Rg Veda, la siguiente es la definición de lo que es un mantra según el pensamiento antiguo:

Palabra o palabras que se cree que son de "origen suprahumano", recibidas, modeladas y declaradas por los videntes, poetas y recitadores "inspirados", para evocar un poder o unos poderes divinos, y especialmente concebidas como medios para crear, comunicar, concentrar y realizar el pensamiento intencional y eficiente, $y$ de tener contacto o identificarse uno mismo con la esencia de la divinidad, la cual está presente en el mantra. ${ }^{68}$

El punto es que los versos sacros tienen como uno de sus propósitos fundamentales que la persona se identifique a sí misma con la esencia de la divinidad a la que está dedicando su alabanza.

Dirección institucional del autor:

Centro de Estudios de Asia y África

El Colegio de México

Camino al Ajusco 20

Pedregal de Santa Teresa

10740, México, D.F.

凶ahquiroz@colmex.mx

${ }^{68}$ Jan Gonda, Selected Studies, Leiden, Brill, 1975, vol. 1, p. 259. 


\section{Bibliografía}

Aitareya Brāhmaṇa, ed. R. Anantakṛṣna Śāstri, con el comentario de Șadguruśișya, Trivandrum, Bhaskara Press, 1942.

Der Rig-Veda, tr. Karl Friedrich Geldner, Londres, Harvard University Press, 1951, vol. 1.

Doniger O'Flaherty, Wendy, The Rig Veda: An Anthology, Middlesex, Penguin Books, 1981.

GondA, Jan, Selected Studies, Leiden, Brill, 1975, vol. 1.

HalbFass, Wilhelm, Tradition and Reflection: Explorations in Indian Thought, Nueva York, State University of New York Press, 1991. Hymns of the Rigveda, tr. Ralph T. H. Griffith, Varanasi, The Chowkhamba Sanskrit Series, 1963, vol. 1.

Íśádidaśopanișadah śánkarabhāșyasametāh, con el comentario de Śankara, Delhi, Motilal Banarsidass, s.f.

IsaYeVA, Natalia, "Shankara and Indian Philosophy", Nueva York, State University of New York Press, 1993.

JosHI, Rasik Vihari, "The Doctrine of 'Aham-artha", en Ram Karan Sharma (ed.), Researches in Indian and Buddhist Philosophy. Essays in Honour of Professor Alex Wayman, Delhi, Motilal Banarsidass, 1993, pp. 247-280.

KnIPE, David M., “The Heroic Theft: Myths from R.gveda IV and the Ancient near East", History of Religions, vol. 6, núm. 4, mayo de 1967, pp. 328-360.

Lubotsky, Alexander, A Rgvedic Word Concordance, 2 vols., Connecticut, American Oriental Society, 1997.

Mahadevan, Thennilapuram P., "The Rsi Index of the Vedic Anukraman̄i System and the Pravara Lists: Toward a Pre-history of the Brahmans", Electronic Journal of Vedic Studies, vol. 18, núm. 2, 2011, pp. 1-139.

Monier Williams, Sir Monier, A Sanskrit-English Dictionary, Delhi, Sri Satguru Publications, 2005.

Nakamura, Hajime, A History of Early Vedānta Philosophy, Delhi, Motilal Banarsidass, 1983.

PotTer, Karl. H., Advaita Vedānta up to Śạkara and His Pupils, Nueva Jersey, Princeton University Press, 1981.

Rig Bhashya of Sri Madbvacharya, introducción de K. T. Pandurangi, e-book publicado por tatvavada.org. [www.tatvavada.org/eng/ works/pdf/rgb.pdf, consultado el 29 de enero de 2015.]

Rig-Veda-Sambitā: The Sacred Hymns of the Brāhmanas, ed. Max F. Müller, con los comentarios de Sāyānāāārya, Varanasi, The Chowkhamba Sanskrit Series, 1966, vol. 2. 
The Aștāadhyāyì of Pānini, ed. Sumitra Mangesh Katre, Austin, University of Texas Press, 1987.

The Brahmasūtra-Śä̀nkara-Bhāsya, ed. E. A. Soloman y K. L. Joshi, con los comentarios Bhāmatì, Kalpataru y Parimala, Delhi, Parimal Publications, 1982, vol. 1.

The Bṛhadāranyaka Upanișad, tr. Swami Madhavananda, con el comentario de Śañkarācārya, Kolkata, Advaita Ashrama, 2004.

The Brhad-devata: Attributed to Saunaka: A Summary of the Deities and Myths of the Rig-veda, tr. Arthur Anthony Macdonell, Delhi, Motilal Banarsidass, 1965.

The Early Upanișads, tr. Patrick Olivelle, Nueva York, Oxford University Press, 1998.

The Nighantu and the Nirukta of Śri Yāskācārya, tr. Lakshman Sarup, Delhi, Motilal Banarsidass, 2009.

The Rigveda: Metrically Restored Text, eds. Karen Thomson y Jonathan Slocum, Austin, The University of Texas, s.f. [www. utexas.edu/cola/centers/lrc/RV/RV00.html, consultado el 30 de enero de 2015.]

The Rigveda: The Earliest Religious Poetry of India, tr. Stephanie W. Jamison y Joel P. Brereton, Nueva York, Oxford University Press, 2014, vol. 1.

Thompson, George, "Ahamkāra and Ātmastuti: Self-Assertion and Impersonation in the Rgveda”, History of Religions, vol. 37, núm. 2, noviembre de 1997, pp. 141-171.

Witzel, Michael, "Autochthonous Aryans? The Evidence from Old Indian and Iranian Texts", Electronic Journal of Vedic Studies, vol. 7, num. 3, 2001, pp. 1-115. 